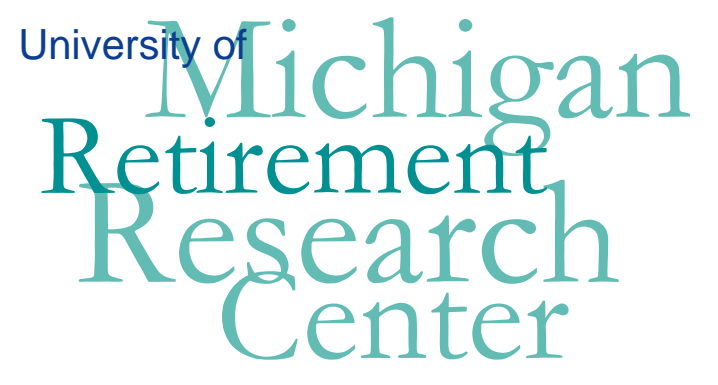

Working Paper

WP 2009-216

Financial Literacy and Financial Sophistication in the Older Population: Evidence from the 2008 HRS

Annamaria Lusardi, Olivia S. Mitchell, and Vilsa Curto

\begin{tabular}{|l|l|l|l|l|l|l}
\hline $\mathrm{M}$ & $\mathrm{R}$ \\
\hline $\mathrm{R}$ & $\mathrm{C}$ & Project \#: UM09-10 \\
\hline
\end{tabular} 



\title{
Financial Literacy and Financial Sophistication in the Older Population: Evidence from the 2008 HRS
}

\author{
Annamaria Lusardi \\ Dartmouth College \\ Olivia S. Mitchell \\ The Wharton School \\ Vilsa Curto \\ Harvard University \\ September 2009 \\ Michigan Retirement Research Center \\ University of Michigan \\ P.O. Box 1248 \\ Ann Arbor, MI 48104 \\ http://www.mrrc.isr.umich.edu/ \\ (734) 615-0422
}

\section{Acknowledgements}

This work was supported by a grant from the Social Security Administration through the Michigan Retirement Research Center (Grant \# 10-M-98362-5-01). The findings and conclusions expressed are solely those of the author and do not represent the views of the Social Security Administration, any agency of the Federal government, or the Michigan Retirement Research Center.

\section{Regents of the University of Michigan}

Julia Donovan Darrow, Ann Arbor; Laurence B. Deitch, Bingham Farms; Denise Ilitch, Bingham Farms; Olivia P. Maynard, Goodrich; Andrea Fischer Newman, Ann Arbor; Andrew C. Richner, Grosse Pointe Park; S. Martin Taylor, Gross Pointe Farms; Katherine E. White, Ann Arbor; Mary Sue Coleman, ex officio 


\title{
Financial Literacy and Financial Sophistication in the Older Population: Evidence from the 2008 HRS
}

\begin{abstract}
This paper analyzes new data on financial literacy and financial sophistication from the 2008 Health and Retirement Study. We show that financial literacy is lacking among older individuals and for the first time explore additional questions on financial sophistication which proves even scarcer. For this sample of older respondents over the age of 55, we find that people lack even a rudimentary understanding of stock and bond prices, risk diversification, portfolio choice, and investment fees. In view of the fact that individuals are increasingly required to take on responsibility for their own retirement security, this lack of knowledge has serious implications.
\end{abstract}

\section{Authors’ Acknowledgements}

Additional support was provided by the Pension Research Council and Boettner Center at the Wharton School of the University of Pennsylvania, and FINRA Investor Education Foundation. 


\title{
Financial Literacy and Financial Sophistication in the Older Population: Evidence from the 2008 HRS
}

\author{
Annamaria Lusardi, Olivia S. Mitchell, and Vilsa Curto
}

\section{RESEARCH QUESTION AND POLICY RELEVANCE}

Financial literacy among Americans is disappointingly low. For instance, only half of older respondents surveyed in a special module of the 2004 Health and Retirement Study (HRS) could correctly answer two simple questions regarding inflation and compound interest. Only one-third correctly answered these two questions as well as a third question about risk diversification (Lusardi and Mitchell, 2006, 2008a). Evidence of low numeracy and low financial sophistication is also evident for younger respondents (Lusardi and Mitchell, 2007a; Lusardi, Mitchell and Curto, 2009) in surveys including the Rand American Life Panel (ALP) and the Survey of Consumers (Lusardi and Mitchell, 2007c; Hilgert, Hogarth, and Beverly, 2003). Financial illiteracy is also particularly acute among specific demographic sub-groups, such as women, minorities, and those with low income and education (Lusardi and Mitchell, 2007b, 2008a). Lack of financial literacy has important consequences; those who lack literacy are much less likely to plan for retirement (Lusardi and Mitchell, 2006, 2007a, 2007c), are more likely to end up with less wealth close to retirement (Lusardi and Mitchell, 2007a), are less likely to invest in stocks (van Rooij, Lusardi and Alessie, 2007; Kimball and Shumway, 2006; Yoong , 2007), and are more likely to use high-cost means of borrowing (Lusardi and Tufano, 2009).

This paper analyzes new data from the 2008 HRS on financial literacy and financial

sophistication. ${ }^{2}$ We assess levels of financial sophistication among older individuals, specifically persons over the age of 55 in 2008. Many prior studies focused on simple measures of basic

\footnotetext{
2 This module was designed by Miles Kimball and Tyler Shumway in collaboration with the authors of this paper.
} 
financial literacy and did not consider financial sophistication. Our research is informative for policy in several ways. First, results from this research can be used to design financial education programs that are more effective in fostering financial literacy and saving. By examining knowledge about the behavior of the stock market, basic asset pricing, and the importance of mutual fund fees on long-term investments, explicit suggestions can be provided regarding topics that should be covered in financial education programs. Second, this paper identifies which population groups are most likely to be financially unsophisticated. Third, the analysis indicates which groups are most prone to poor financial decision-making at older ages and provides some suggestions for improving the effectiveness of financial education programs.

\section{PREVIOUS RESEARCH}

Older Americans are not particularly financially literate, as shown by Lusardi and Mitchell (2006) using data from a special-purpose module the authors created for the 2004 HRS. These findings have been confirmed among Early Baby Boomers, who displayed not only low numeracy, but also a lack of knowledge of fundamental economic concepts such as interest rate compounding (Lusardi and Mitchell, 2007a). Moreover, particular sub-groups of the population suffer even greater deficits in financial literacy; Lusardi and Mitchell (2008a) find that women display much lower literacy than men and are much less likely to plan for retirement. Furthermore, minorities and those with low education and low income are more likely to display low levels of financial knowledge (Lusardi and Mitchell, 2007b; Lusardi, 2008b; Smith and Stewart, 2008).

These results are troublesome given the increasing complexity of financial instruments and the many transactions households must undertake that require sound economic 
understanding. For instance, Moore (2003) found that mortgage borrowers in Washington State knew little about compound interest and were confused about the terms of their mortgages. Campbell (2006) found that many households failed to refinance their mortgages over the 20012003 period, when interest rates were falling.

Furthermore, financial illiteracy can have significant long-term financial consequences (Lusardi, 2008a). For example, those who underestimate the power of interest compounding are more likely to end up with excessive amounts of debt (Lusardi and Tufano, 2009). Those who fail to refinance or to correctly estimate the amount by which interest rates could change will pay significantly more in mortgage interest (Campbell, 2006).

\section{RESEARCH DATA AND METHODOLOGY}

Most of the financial literacy studies mentioned above have drawn on evidence gathered in a short experimental module in the 2004 HRS designed by Lusardi and Mitchell. ${ }^{3}$ This set of questions has been used very successfully to explore the links between financial literacy and retirement planning as well as retirement wealth accumulation. Nevertheless, that module included only three questions designed to assess basic numeracy and knowledge of basic economic concepts such as inflation and risk diversification. For this reason, we have sought to expand the scope of investigation into financial knowledge among the older population with additional questions added to other surveys. For instance we have developed questions on financial knowledge in the American Life Panel which we first piloted on the Dutch DNB Household Survey (Lusardi and Mitchell, 2007c; van Rooij, Lusardi and Alessie, 2007). These new measures cover not only basic but also sophisticated financial knowledge, eliciting

\footnotetext{
${ }^{3}$ These questions have now been added to related surveys in Germany, Italy, the Netherlands, Russia, New Zealand, Japan, Chile, and Mexico, revealing similar patterns of widespread illiteracy.
} 
knowledge on the difference between bonds and stocks, the working of the stock market, and basic asset pricing. In turn, this expanded set of data about financial knowledge then influenced the wording of the new module for the 2008 HRS, to be described in more detail below. Using this extended information, we can now classify respondents not only in terms of basic financial literacy but also in terms of financial sophistication.

An interesting aspect of the 2008 HRS module on financial literacy is its innovative approach to assessing how the literacy questions are designed. Not only is there a richer list of questions compared to the $2004 \mathrm{HRS}$, but also respondents are presented with alternative question wording to assess whether respondents are guessing or whether they actually understand the questions. Specifically, respondents are randomly chosen to be presented with the same questions but with reverse wording. For example, one set of respondents is asked whether the following statement is true or false: "If you invest for the long run, the annual fees of mutual funds are important;" the second group is asked: "If you invest for the long run, the annual fees of mutual funds are unimportant." Such wording reversal permits us to begin to evaluate the extent of measurement error in responses to financial sophistication questions. This is a very important methodological innovation. Both the Dutch DNB Household Survey and the ALP used a similar approach for a small subset of the questions, and there we showed that the wording of the questions does matter, particularly for questions measuring financial sophistication (Lusardi and Mitchell, 2007c, 2009; van Rooij, Lusardi and Alessie, 2007). In general, if people are financially unsophisticated, it will be difficult to elicit accurate responses to unfamiliar concepts. 


\section{MEASURING FINANCIAL SOPHISTICATION}

In 2008, a subset of some 1332 HRS respondents responded to a battery of questions seeking to assess their knowledge of the stock market, asset pricing, investment strategies, risk diversification, the importance of fees, financial attitudes and related topics. Because so many questions are asked to respondents, we have organized them into five different sub-groups according to the topics they cover, as follows (exact question wording appears in the Appendix):

\section{(A) Knowledge of capital markets}

V407 Understanding of the stock market

V408 Investment in company stocks

V408 Avoidance of foreign stocks

V416 Bond value versus interest rate

\section{(B) Risk diversification}

V411 Invest in few stocks

V417 Stock risk spread

V419 Diversify stocks

(C) Knowledge of fees

V415 Importance of annual fees

V418 Asset annual fees

\section{(D) Savvy/numeracy}

V412 Buy/sell stocks often

V413 Enough life insurance

V422 Use savings in bank to pay off credit cards

V423 Power of interest compounding 


\section{(E) Attitudes toward investing and risk}

V406 All money in safest asset

V410 Whether older retired should hold stocks

V420 Smart people select stocks with good return

V421 Stock market equals lottery

V424 Advisors take unfair advantage

Respondents to this module were, on average, age 67, with about 55\% female. About 16\% had less than high school education, 33\% had high school, 24\% had some college, and 28\% had college or advanced degrees. The majority, 81\%, of the respondents was White, 9\% AfricanAmerican, and 8\% Hispanic. Summary statistics on outcomes appear in Tables 1-5, and detail by sex, age, and education in Tables 6-9.

\section{A. Knowledge of capital markets}

Recalling that this module was fielded in 2008, a year of particularly volatile capital markets, it is probably not surprising that a large majority of respondents reported that they did not understand this market; only about $30 \%$ said they did. Nevertheless the degree of financially illiteracy extends much more broadly, supporting the view that older Americans lack an understanding of key concepts related to stock prices, risk diversification, and portfolio choice (Table 1). For instance, many respondents expressed a preference for having some company stocks, though there is some sensitivity to the way the question was asked. Respondents given the first wording of this question (whether an employee of a company with publicly traded stock should have a lot of his/her retirement savings in the company stock) did believe that holding a lot a company stocks is not a good idea. Yet when presented with the reverse wording, most 
rejected the idea of holding little or no money in company stock. Since the typical worker will have a large part of his total wealth in human capital which is highly correlated with his employer's financial stability, it is likely to be unwise from a risk diversification viewpoint to hold own employer stock.

The results also show that respondents were wary of investing in international equity. Experts have long argued that international diversification helps diversify risk and offers exposure to fast-growing foreign economies. Nevertheless, many prior studies have found evidence of "home bias," and this is also evident among older respondents (French and Poterba, 1991). It is interesting that the wording of the question matters: respondents were more likely to display financial sophistication when they were asked if it is best to avoid stocks of foreign companies, rather than if it is a good idea to own stocks of foreign companies.

Table 1 also shows that a large majority of respondents did not know about asset pricing, which we have tested by asking whether people know about the inverse relationship between bond prices and interest rates. This is a particularly good question to assess financial sophistication because, while some questions may be answered correctly if people are good at math or are clever and can figure out an answer, it is hard if not impossible to know or infer the correct answer to this question without having some knowledge of finance. When we piloted this question in both the ALP and the Dutch DNB, we found that a small share (fewer than half) of respondents knew about bond pricing, and also the wording of this question mattered. We confirm this finding for the present module as well. When presented with the statement if interest rates fall, bond prices will rise, only about one-third (36\%) of respondents answered correctly; the wording was reversed and people were asked if interest rates fall, bond prices will fall , many more are correct. This may be due to guessing, since a sizable proportion of respondents (as 
many as 23\%) reported they did not know the answer to this question. ${ }^{4}$ Note too that answers to these questions are not highly correlated and only 6\% could respond correctly to all four questions. Moreover, more than a fourth answered "do not know" to at least one of the questions.

\section{B. Knowledge of risk diversification}

Knowledge of risk diversification is very important when contemplating investment options. Table 2 shows that many respondents (over 60\%) seemed to know that it is not a good idea to invest in a few stocks rather than in many stocks or in mutual funds, which may imply some sophistication about risk. Moreover, the large majority seemed to know that spreading money across 20 stocks rather than two decreases the risk of losing money. Yet again the way both questions are worded matters, indicating that some respondents were simply guessing. We hypothesize that some of the sensitivity to how the questions are asked could be due to economic terminology. For instance, many respondents may not know what a mutual fund is or the fact that mutual funds contain many stocks. Finally, close to half of the respondents agreed that by diversifying, one could invest more in stocks; now there is little sensitivity to question wording, perhaps because this question does not require much knowledge beyond what a stock is.

While each individual question seems to indicate some knowledge and understanding of risk diversification, only one-third (32\%) of respondents answered correctly to all three questions and 23\% responded "do not know" to at least one question, showing that their knowledge was limited to one specific concept.

\section{Knowledge of fees}

\footnotetext{
${ }^{4}$ In prior research we have found that those who respond that they "do not know" are also those who are least financially knowledgeable (Lusardi and Mitchell, 2006).
} 
Two questions in the module seek to assess peoples’ knowledge of fees associated with investments; see Table 3. This is important since higher fees erode retirement wealth, yet prior studies have shown that investors often overlook fees when deciding how to invest (Choi, Laibson and Madrian, 2009; Mitchell, Todd and Bravo, 2008). In our sample, a sizable percentage (60\%) seemed to know that mutual fund fees are important when investing for the long run, but the responses are sensitive to the wording of the questions, perhaps due to the fact that the respondent would have to know both about mutual funds and what investing for the long run means. Note also that a large majority of respondents found it difficult to locate mutual funds with annual fees of less than one percent of assets, suggesting that many respondents may not know about indexed funds. Moreover, only about one-quarter (28\%) of respondents evinced some financial sophistication with respect to fees by answering both questions correctly, while more than 30\% responded "do not know" to at least one of these two questions.

\section{Savvy/numeracy}

While it is important to evaluate whether people know about fees, it is also important to know whether they pursue behaviors that could reduce fees. Table 4 shows what respondents knew regarding the question of whether "to make money in the market they should not buy and sell stocks too often.” Most respondents (over 60\%) seemed to be savvy with regard to buying and selling stocks. Similarly, many respondents (almost 70\%) were savvy about life insurance and, for example, knew that replacing three years of income would be inadequate coverage for a family with a working husband and a wife who stays home to take care of young children. Most respondents also knew that using money in a bank account to pay off credit card debt is usually a good idea. 
Probably due to their simplicity, those questions elicit responses that are insensitive to question wording. This is, however, not the case for a different query asked to assess whether people know about the power of interest compounding and their ability to do rather complex calculations involving interest rates. Over half seemed to be able to figure out that an initial investment of $\$ 1,000$ would grow more than six-fold when invested at an interest rate of $10 \%$ for 30 years. Nevertheless the alternative wording generates different answers, so at least some were guessing. Moreover, only one quarter (22\%) were able to give correct answers to all four questions, and another quarter (22\%) responded with "do not know" to at least one of these questions.

\section{E. $\quad$ Attitudes toward investing and risk}

Other questions in the module measure financial attitudes; see Table 5. One focuses on older persons' willingness to accept investment risk. It is interesting that a large majority of the older respondents (68\%) did not agree that "one should put all money into the safest investment and accept whatever return it pays," a notable finding given the timing of the survey. And most respondents thought that even older retired households should hold some stocks, a finding very much in line with the willingness to accept some risk displayed in the responses to the first question. Many respondents were also aware that "even if one is smart, it is very difficult to pick individual stocks that will have better than average returns." In the latter case, however, responses were vastly different depending on how the question was asked. Most respondents also knew that investing in the stock market is better than buying lottery tickets, and that it is incorrect to think that one has to be taken advantage of when investing in the stock market. 
While responses to these questions do seem to pick up some sophistication among respondents, the fact that the question wording matters so much casts some doubt on whether respondents were informed or simply guessing. Furthermore, since only one fifth of respondents could answer all questions correctly and one fifth responded "do not know" to at least one question, the evidence is indicative of widespread shortcomings in financial sophistication.

\section{WHO KNOWS THE LEAST?}

As shown above, there is some evidence of financial sophistication when assessing the answers to a large set of questions, but sophistication seems limited to a specific concept and the fraction of respondents that can be considered sophisticated, at least judging from their responses to this set of questions, is hardly above $25 \%$. Next we explore how responses to these questions vary by sex, education, age, and race/ethnicity.

Table 6 shows that older women were substantially less likely than older men to report they understood the stock market reasonably well. And while they did not differ much in how they would invest in company stock, women were more likely to avoid investing in foreign stocks. Moreover, they were less likely to be knowledgeable about asset pricing, i.e., the relationship between bond prices and interest rates. They were also less knowledgeable than men about risk diversification; for example, they were less likely to know that spreading money across many stocks decreases the risk of losing money. This raises the question of whether some of the attitudes toward risk that women display are due to preferences or to financial sophistication.

In terms of knowledge about fees, women were similar to men and sometimes they seemed to know more. Further, their financial savvy was similar to men's and in some cases, 
they were more knowledgeable about adequate life insurance and how to be savvy about credit cards. Nevertheless, women performed substantially less well in terms of numeracy and complex calculations than men, confirming our findings from other surveys (Mitchell and Lusardi, 2006, 2008, 2009). We also note that the attitudes of women were not very different from those of men, and while women tended to score a little lower than men in these questions, differences were often not statistically significant.

Overall, there was a gender gap in terms of financial sophistication between women and men. Women were less knowledgeable about some of the complex concepts of finance and investing, such as the working of the stock market, risk diversification, and asset pricing. They also had more difficulty in doing complex calculations. Because women were more likely to respond that they do not know the answers to the questions, they are more likely to be classified among those with low knowledge. Of course, awareness of lack of knowledge could help women acquire knowledge or become more active in seeking for help and counseling (Lusardi, Keller and Keller, 2008).

Table 7 reports how financial sophistication varies by educational level. Overall, the proportion of sophisticated respondents increases monotonically as we move to higher educational attainment and it is highest for those with at least a college degree. Some of the differences are quite staggering. For example, only $14 \%$ of those with less than a high school degree stated that they know how the stock market works reasonably well. For those with at least a college degree the percentages are far higher, though even here, fewer than half agreed with this assessment. These are worrisome statistics, in view of the shift in responsibility from employers to workers for saving and investing retirement wealth. Similarly, only one third (31\%) of respondents with less than a high school degree thought it was a good idea to invest in foreign 
stocks; the share increases steadily across higher levels of education and more than doubles (66\%) among those with a college degree. This suggests that financial sophistication can be an important determinant not only of stock market participation but also of the types of portfolios that investors hold. Similarly, we find that the knowledge of asset pricing was very low among those with less than a high school degree (23.5\%), while it increased to more than $50 \%$ for the college educated.

Across all questions measuring risk diversification, there is a steep education gradient, so the financially sophisticated tend be the most educated. This is true even for questions that do not use economic terminology (e.g. do not require knowing what a mutual fund is and how it operates). For example, the least educated were much less likely to know that holding 20 rather than two stocks decreases the risk of losing a lot of money.

With respect to fees, less educated respondents were unlikely to be aware of the importance of fees, but there are no significant differences across educational grouping as to the difficulty of finding low-cost mutual funds. We take this to imply that knowledge of indexed funds is not widespread even among the educated, and/or that search and time costs are high for most groups. Financial savvy was lower among those with less education; those respondents were less skillful in doing complex calculations and in credit card debt management, a finding consistent with other surveys (Lusardi and Tufano, 2009). It probably means that those with the least knowledge will pay higher interest rates on their debt. It may be that the tendency to invest in the safest investment is a proxy for having little knowledge, rather than risk aversion.

Responses to the financial sophistication questions also differed across age groups; see Table 7. Few over age 75 understood the working of the stock market or were willing to buy foreign stock, perhaps reflecting the fact of limited exposure to stock markets. Knowledge about 
risk diversification declined steadily with age: older respondents were much less likely to know how to decrease risk when investing in stocks, even when questions were phrased simply. Many respondents stated that fees were important, but older respondents found it more difficult to locate low-fee mutual funds. This might be due to their lesser facility with the internet or reduced cognitive ability. People age 75+ seemed less savvy as well; they were less likely to know that one loses money by trading stocks often or how to manage credit card debt, and they were less likely to be correct in complex calculations about interest compounding. Older investors were also more wary of being taken advantage of in the stock market, consistent with their lower levels of financial sophistication.

In Table 9 we summarize differences across race/ethnicity. Knowledge about the stock market low was particularly low among African-Americans and Hispanics, where only 21\% and $15 \%$, respectively, reported that they understood the stock market reasonably well. This lesser knowledge was also apparent in responses to questions about company stock, foreign stocks, and asset pricing. Sharp differences in knowledge also emerged regarding risk diversification. Even when questions did not refer to concepts such as mutual funds, the percentage of respondents knowing about risk diversification was much lower among African-Americans and Hispanics. Nonwhites were also less likely to know about adequate life insurance, that stock market trading is costly, and that is a good idea to pay off credit cards with bank saving. They were also less likely to be correct in calculations involving interest compounding. Some of the answers to these questions may simply pick up the limited experience that respondents have with stocks and bonds, and also with credit cards. Note also that the attitudes of African-Americans and Hispanics differed markedly from those of White respondents. For example, Hispanics were substantially more likely to think they should put all of their money in the safest investment they 
can find and accept whatever return it pays. Moreover, they were more likely to think that "investing in the stock market is no better than buying lottery tickets," and that "there is no way to avoid people taking advantage of you if you invest in the stock market." These findings are supportive of prior surveys on differences in financial literacy by race/ethnicity (Lusardi and Mitchell, 2006, 2007a, 2007b, 2009).

\section{IMPLICATIONS}

In this paper, and in much of our earlier work, we have found substantial shortfalls in older persons' levels of financial literacy and financial sophistication. The value-added of the present research is to illuminate key areas where more could be done to inform, educate, and deepen peoples' understanding of what must be done to diversify investments, reduce costs, and make retirement saving more effective. We have used an extensive module fielded in the 2008 HRS to explore knowledge about capital markets and risk diversification, knowledge of fees, financial savvy/numeracy, and attitudes toward investing and risk. We also exploit differences in question wording to gain insight into whether respondents are guessing or actually know the answers to the questions posed.

For this sample of older respondents over the age of 55, we find that people lack even a rudimentary understanding of stock and bond prices, risk diversification, portfolio choice, and investment fees. Furthermore, people that got one question correct were not particularly likely to get others correct, and “do not know” responses were quite widespread. Simpler questions that avoided economic jargon were easier to answer. We also conclude that the way in which the questions were framed mattered: for instance, 38\% answered correctly when asked to opine on the following statement: "it is easy to pick individual company stock that will have better than 
average returns" whereas $74 \%$ answered correctly when the reverse wording was offered "it is hard to pick individual company stock that will have better than average returns." This suggests that more research is needed on the way in which financial sophistication questions are framed, to evaluate whether and how to help people develop a fuller understanding of how retirement saving and investment work.

This analysis may be of use to policymakers working to enhance retirement security. It is clear that employees and retirees are increasingly being asked to take on tasks requiring financial sophistication, including making saving, investment, and dissaving decisions for retirement. Our research suggests that it may be particularly important to build retirement human capital via seminars, educational programs, and retirement planning products. Nevertheless, one-size-fits-all programs are unlikely to successfully address saving shortfalls particularly among the elderly, given the very different patterns we have discerned by sex, age, educational levels, and race/ethnicity. Instead, programs must be targeted so as to address fundamental differences in preferences, saving needs, and financial knowledge as well as sophistication. 


\section{APPENDIX}

The specific questions we used in this analysis, along with their question numbers as reported in the Special Purpose Module for HRS 2008, are listed as below.

Additional information on the module is available at http:/hrsonline.isr.umich.edu/modules/meta/2008/core/qnaire/online/Module8_FinancialSophisti cation.pdf

V406_ALL MONEY SAFEST

Please indicate whether you think each statement is true or false.

If you are not sure, give your best guess.

You should put all your money into the safest investment you can find and accept whatever return it pays.

/"All money in safest investment"

V407_UNDERSTAND STOCK MARKET

(Please indicate whether you think each statement is true or false.

If you are not sure, give your best guess.)

I understand the stock market reasonably well.

/"Understand stock market well"

V408_INVESTCOMPANY STOCK

An employee of a company with publicly traded stock should

have [a lot/little or none] of his or her retirement savings in the company's stock.

/"Should employee invest in company stock"

V409_AVOID FOREIGNS TOCKS

It is [best to avoid owning/a good idea to own] stocks

of foreign companies.

/"Should own foreign stocks"

V410_RETIRED HOLD STOCKS

[Even older/Older] retired people should [hold some/not hold

any] stocks.

/"Should older people hold stocks"

V411_INVEST FEW STOCKS

(Please indicate whether you think each statement is true or false. If you are not sure, give your best guess.) You should invest [most of your money in a few good stocks that you select rather than in lots of stocks or in mutual funds/

in either mutual funds or a large number of different stocks instead of just a few stocks]. 
/'Invest in few vs many stocks"

V412_BUY SELL STOCK SOFTEN

To make money in the stock market, you [should not/have to] buy and sell stocks [too/ ] often.

/"Buy and sell often"

V413_ENOUGH LIFE INSURANCE

For a family with a working husband and a wife staying home to take care of their young children, life

insurance that will replace three years of income is [not/more than] enough life insurance.

/"How much life insurance"

V414_SELLS TOCKS VALUE UP DOWN

If you have to sell one of your stocks, you should sell one which has gone [up/down] in price rather than one which has gone [down/up].

/"Sell when stocks up or down"

\section{V415_IMPORTANCE ANNUAL FEES}

If you invest for the long run, the annual fees of mutual funds are [unimportant/important].

/'Importance of annual fees"

\section{V416_BOND VALUE VS INTEREST RATE}

(Please indicate whether you think each statement is true or false. If you are not sure, give your best guess.) If the interest rate falls, bond prices will [rise/fall].

/"Bond value vs interest rate change"

V417_STOCK RISK SPREAD

When an investor spreads money between 20 stocks, rather than 2, the risk of losing a lot of money [decreases/increases].

/"Risk vs number of stocks"

V418_ASSETS ANNUAL FEES

It is [hard/easy] to find mutual funds that have annual fees of less than one percent of assets.

/"Low annual fees hard or easy to find"

V419_DIVERSIFY STOCKS

The more you diversify among stocks, the [more/less] of your money you [can/should] invest in stocks. 
/"Amount invest vs stock diversification"

V420_SELECT FOR GOOD RETURN

(Please indicate whether you think each statement is

true or false. If you are not sure, give your best guess.)

[If/Even if] you are smart, it is [easy/hard] to pick

individual company stocks that will have better than

average returns.

/"Pick stocks with good returns"

V421_INVESTMENT EQUALS LOTTERY

Financially, investing in the stock market is [no better/better] than buying lottery tickets.

/’Stock market like lottery"

V422_USE SAVINGS PAY OFF CC DEBT

Using money in a bank savings account to pay off credit card debt is usually a [good/bad] idea.

/"Use savings pay off credit card debt"

V423_GROWTH OF INVESTMENT

If you start out with $\$ 1,000$ and earn an average return of $10 \%$ per year for 30 years, after compounding, the initial \$1,000 will have grown to [more/less] than $\$ 6,000$.

/"Growth of investment"

V424_ADVISOR UNFAIR ADVANTAGE

[There is no way to avoid people taking advantage of you if you invest in the stock market./

It's possible to invest in the stock market in a way that makes it hard for people to take unfair advantage of you.]

/’Do advisors take unfair advantage" 


\section{REFERENCES}

Campbell, John (2006), “Household Finance,” Journal of Finance, 61, pp.1553-1604.

Choi, James, David Laibson and Brigitte Madrian (2009), "Why Does the Law of One Price Fail? An Experiment on Index Mutual Fund,” Working Paper, Harvard University and forthcoming in the Review of Financial Studies.

French, Kenneth and James Poterba (1991), "Investor Diversification and International Equity Markets," American Economic Review 81, 222-226.

Hilgert, Marianne, Jeanne Hogarth, and Sondra Beverly (2003), "Household Financial Managament: The Connection between Knowledge and Behavior," Federal Reserve Bulletin, 309-32.

Kimball, Miles and Tyler Shumway (2006), "Investor Sophistication and the Participation, Home Bias, Diversification, and Employer Stock Puzzle,” mimeo, University of Michigan.

Lusardi, Annamaria (2008a), "Household Saving Behavior: The Role of Financial Literacy, Information and Financial Education Programs," NBER Working Paper No 13824, and forthcoming in Implications of Behavioral Economics for Economic Policy.

Lusardi, Annamaria (2008b), "Financial Literacy: An Essential Tool for Informed Consumer Choice?,” Working Paper, Dartmouth College. http://www.dartmouth.edu/ alusardi/Papers/Literacy_ConsumerChoice.pdf

Lusardi, Annamaria and Olivia S. Mitchell (2006), "Financial Literacy and Planning: Implications for Retirement Wellbeing,” MRRC Working Paper n. 2006-144.

Lusardi, Annamaria and Olivia S. Mitchell (2007a), "Baby Boomer Retirement Security: The Role of Planning, Financial Literacy, and Housing Wealth,” Journal of Monetary Economics, 54, pp. 205-224.

Lusardi, Annamaria and Olivia Mitchell (2007b), "Financial Literacy and Retirement Preparedness: Evidence and Implications for Financial Education,” Business Economics, January 2007, pp. 35-44.

Lusardi, Annamaria and Olivia Mitchell (2007c), "Financial Literacy and Retirement Planning: New Evidence from the Rand American Life Panel,” MRRC Working Paper n. 2007-157.

Lusardi, Annamaria and Olivia Mitchell (2008a), "Planning and Financial Literacy. How Do Women Fare?,” American Economic Review, May 2008. 
Lusardi, Annamaria and Olivia Mitchell (2008b), "How Much Do People Know About Economics and Finance? Financial Illiteracy and the Importance of Financial Education,” Policy Brief n. 5, MRRC, March 2008.

Lusardi, Annamaria and Olivia Mitchell (2009), "How Ordinary Consumers Make Complex Economic Decisions: Financial Literacy and Retirement Readiness,” NBER Working Paper n. 15350.

Lusardi, Annamaria, Olivia Mitchell, and Vilsa Curto (2009), "Financial Literacy Among the Young: Evidence and Implications for Consumer Policy,” NBER Working Paper n. 15352.

Lusardi, Annamaria and Peter Tufano (2009), “Debt Literacy, Financial Experience, and Overindebtedness,” NBER Working Paper n. 14808.

Mitchell, Olivia S., Petra Todd, and David Bravo. (2008). "Learning from the Chilean Experience: The Determinants of Pension Switching.” In Annamaria Lusardi, Ed. Overcoming the Saving Slump: Making Financial Education and Saving Programs More Effective. University of Chicago Press, 301-323.

Moore, Danna (2003), "Survey of Financial Literacy in Washington State: Knowledge, Behavior, Attitudes, and Experiences,” Technical Report n. 03-39, Social and Economic Sciences Research Center, Washington State University.

Smith, Barbara and Fiona Stewart (2008), "Learning from the Experience of OECD Countries: Lessons for Policy, Programs and Evaluations.” In Annamaria Lusardi, Ed. Overcoming the Saving Slump: How to Increase the Effectiveness of Financial Education and Saving Programs, University of Chicago Press, 345-367.

van Rooij, Maarten, Annamaria Lusardi and Rob Alessie (2007), "Financial Literacy and Stock Market Participation,” MRRC Working Paper n. 2007-162.

Yoong, Joanne (2007), “Financial Illiteracy and Stock Market Participation,” mimeo, Stanford University. 
Table 1: Knowledge of Capital Markets

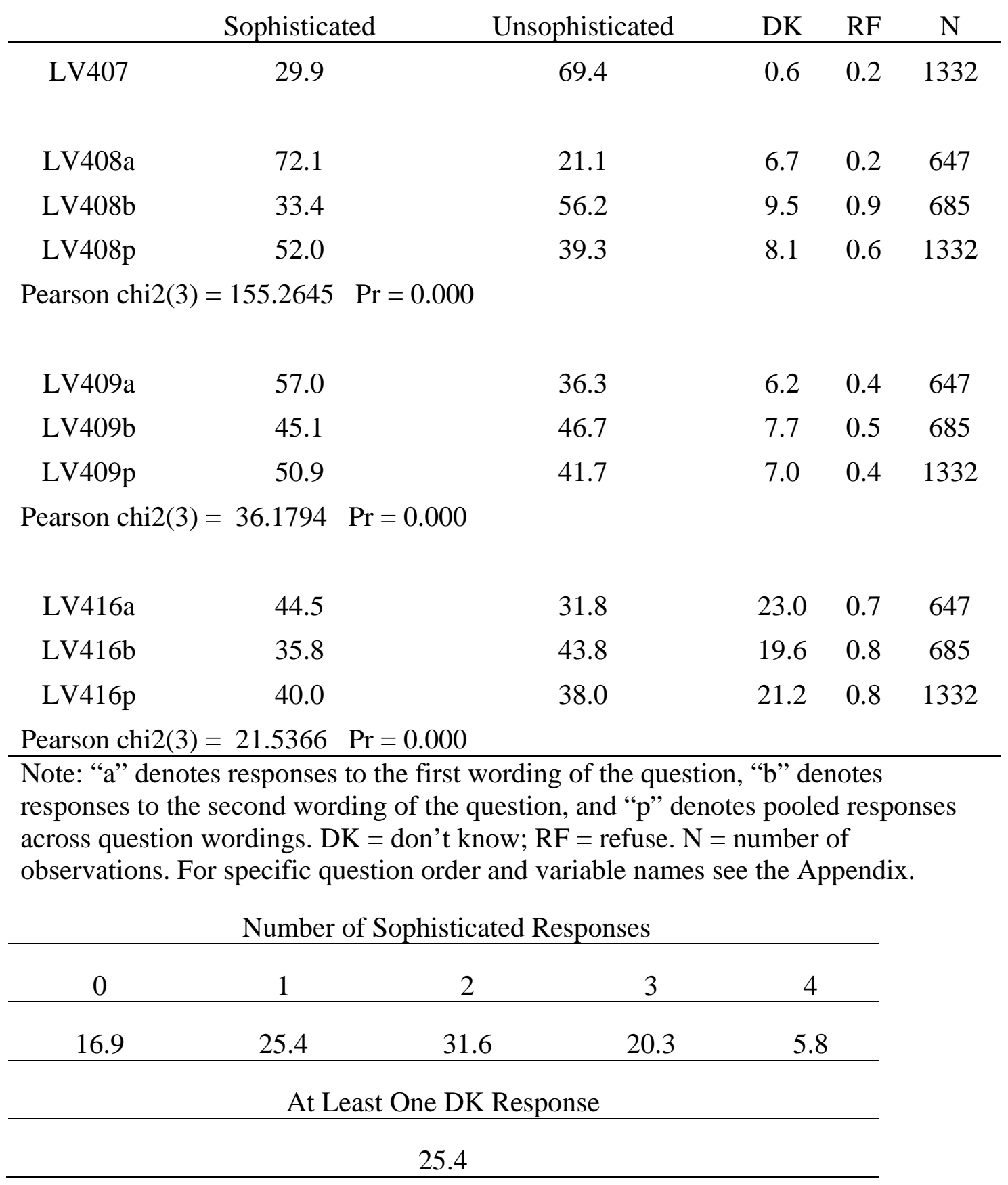


Table 2: Risk Diversification

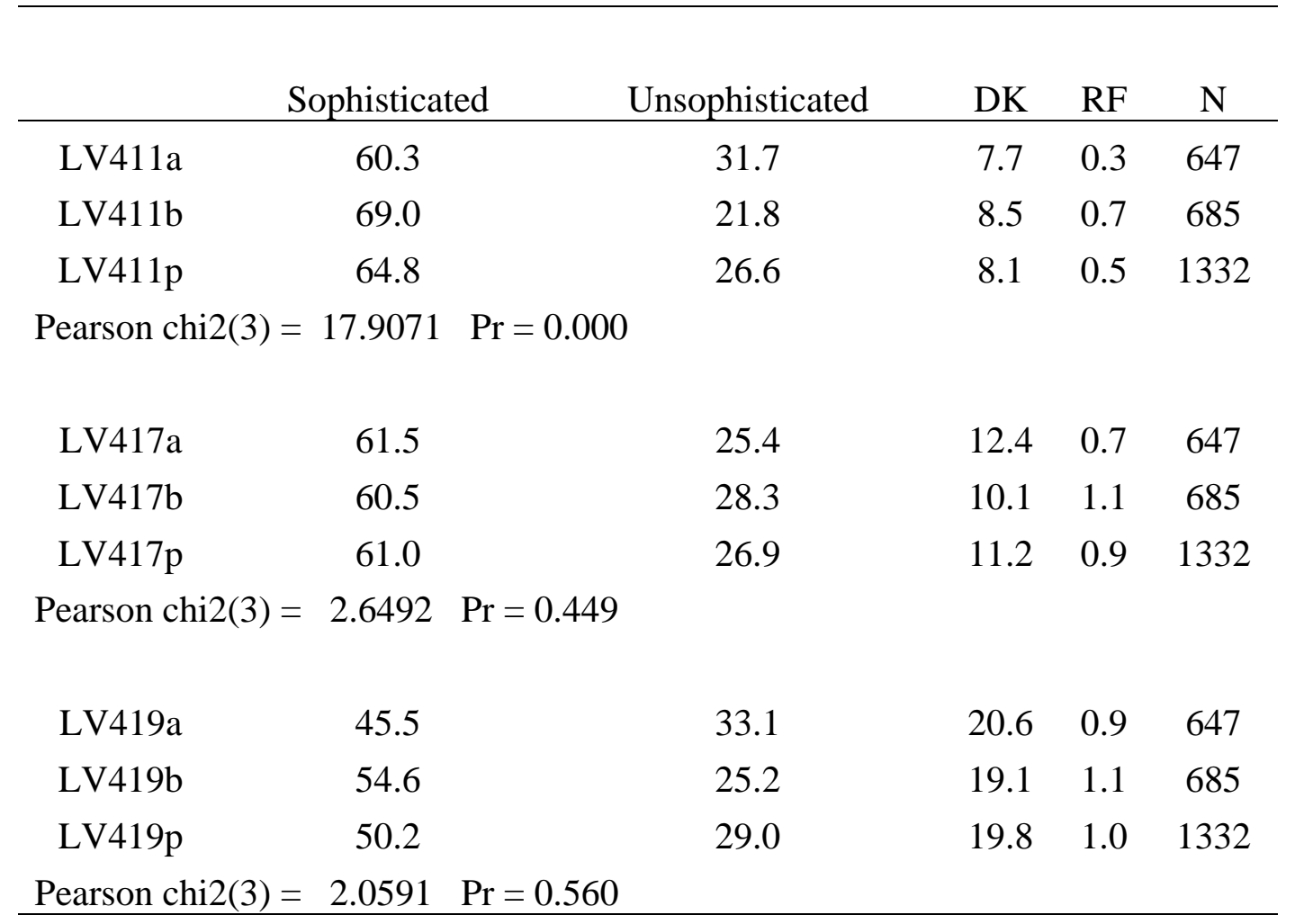

Note: See Table 1.

Number of Sophisticated Responses

\begin{tabular}{cccc}
\hline 0 & 1 & 2 & 3 \\
\hline 15.5 & 24.6 & 28.3 & 31.6 \\
\hline
\end{tabular}

At Least One DK Response 
Table 3: Knowledge of Fees

\begin{tabular}{cccccc} 
& Sophisticated & Unsophisticated & DK & RF & N \\
\hline LV415a & 60.2 & 27.0 & 12.4 & 0.4 & 647 \\
LV415b & 71.3 & 14.9 & 12.5 & 1.2 & 685 \\
LV415p & 66.0 & 20.7 & 12.5 & 0.8 & 1332 \\
Pearson chi2(3) $=39.5088$ Pr $=0.000$ & & & & \\
LV418a & 42.8 & & & & \\
LV418b & 36.2 & 30.0 & 26.4 & 0.9 & 647 \\
LV418p & 39.4 & 32.3 & 30.4 & 1.1 & 685 \\
Pearson chi2(3) $=6.9810 \quad P r=0.073$ & 31.2 & 28.5 & 1.0 & 1332 \\
\hline
\end{tabular}

Note: See Table 1.

\begin{tabular}{ccc}
\multicolumn{3}{c}{ Number of Sophisticated Responses } \\
\hline 0 & 1 & 2 \\
\hline 22.3 & 50.1 & 27.6 \\
\hline
\end{tabular}

At Least One DK Response

30.6 
Table 4: Savvy and Numeracy

\begin{tabular}{|c|c|c|c|c|c|}
\hline Sop & histicated & Unsophisticated & DK & RF & $\mathrm{N}$ \\
\hline LV412a & 62.5 & 29.9 & 7.3 & 0.3 & 647 \\
\hline LV412b & 63.2 & 28.4 & 7.5 & 0.9 & 685 \\
\hline LV412p & 62.8 & 29.1 & 7.4 & 0.6 & 1332 \\
\hline Pearson chi2(3) = & 1.6367 & $\operatorname{Pr}=0.651$ & & & \\
\hline LV413a & 70.3 & 23.6 & 5.8 & 0.4 & 647 \\
\hline LV413b & 69.2 & 22.0 & 8.0 & 0.8 & 685 \\
\hline LV413p & 69.7 & 22.7 & 6.9 & 0.6 & 1332 \\
\hline Pearson chi2(3) = & 2.9379 & $\operatorname{Pr}=0.401$ & & & \\
\hline LV422a & 60.0 & 33.7 & 5.6 & 0.7 & 647 \\
\hline LV422b & 56.8 & 38.9 & 3.5 & 0.9 & 685 \\
\hline LV422p & 58.3 & 36.4 & 4.5 & 0.8 & 1332 \\
\hline Pearson chi2(3) = & 3.4811 & $\operatorname{Pr}=0.323$ & & & \\
\hline LV423a & 69.7 & 14.4 & 14.3 & 1.5 & 647 \\
\hline LV423b & 53.7 & 27.3 & 17.4 & 1.6 & 685 \\
\hline LV423p & 61.4 & 21.1 & 15.9 & 1.6 & 1332 \\
\hline Pearson chi2(3) = & 42.7449 & $\operatorname{Pr}=0.000$ & & & \\
\hline
\end{tabular}

Note: See Table 1.

Number of Sophisticated Responses

\begin{tabular}{ccccc}
0 & 1 & 2 & 3 & 4 \\
\hline 6.7 & 11.6 & 26.9 & 32.4 & 22.4 \\
\hline
\end{tabular}

At Least One DK Response 
Table 5: Attitudes Toward Investing and Risk

\begin{tabular}{|c|c|c|c|c|c|}
\hline \multicolumn{2}{|r|}{ Sophisticated } & Unsophisticated & \multirow{2}{*}{$\frac{\text { DK }}{2.5}$} & \multirow{2}{*}{$\frac{\mathrm{RF}}{0.5}$} & \multirow{2}{*}{$\frac{\mathrm{N}}{1332}$} \\
\hline LV406 & 68.2 & 28.8 & & & \\
\hline LV410a & 65.1 & 30.1 & 4.5 & 0.3 & 647 \\
\hline LV410b & 83.9 & 10.9 & 4.8 & 0.5 & 685 \\
\hline LV410p & 74.8 & 20.2 & 4.6 & 0.4 & 1332 \\
\hline \multicolumn{3}{|c|}{ Pearson chi2(3) $=91.2578 \quad \operatorname{Pr}=0.000$} & & & \\
\hline LV420a & 37.6 & 48.0 & 13.5 & 0.8 & 647 \\
\hline LV420b & 73.6 & 16.4 & 9.0 & 1.0 & 685 \\
\hline LV420p & 56.2 & 31.7 & 11.2 & 0.9 & 1332 \\
\hline \multicolumn{3}{|c|}{ Pearson chi2 $(3)=205.0627 \operatorname{Pr}=0.000$} & & & \\
\hline LV421a & 65.0 & 28.6 & 5.2 & 1.2 & 647 \\
\hline LV421b & 85.2 & 10.0 & 4.1 & 0.7 & 685 \\
\hline LV421p & 75.4 & 19.0 & 4.6 & 1.0 & 1332 \\
\hline \multicolumn{3}{|c|}{ Pearson chi2 $(3)=86.3645 \quad \operatorname{Pr}=0.000$} & & & \\
\hline LV424a & 66.5 & 24.4 & 8.1 & 1.1 & 647 \\
\hline LV424b & 49.9 & 32.8 & 15.7 & 1.6 & 685 \\
\hline LV424p & 57.9 & 28.7 & 12.0 & 1.3 & 1332 \\
\hline Pearson ch & $=36.9570 \mathrm{P}$ & $\operatorname{Pr}=0.000$ & & & \\
\hline
\end{tabular}

Note: See Table 1.

Number of Sophisticated Responses

\begin{tabular}{cccccc}
\hline 0 & 1 & 2 & 3 & 4 & 5 \\
\hline 3.0 & 7.4 & 13.6 & 25.7 & 30.6 & 19.7 \\
\hline
\end{tabular}

At Least One DK Response

19.9 
Table 6: Financial Sophistication by Sex

\begin{tabular}{ccccccc} 
& \multicolumn{3}{c}{ Male (N=577) } & \multicolumn{3}{c}{ Female (N=755) } \\
\hline & Soph & Unsph & DK & Soph & Unsph & DK \\
\hline LV406 & 67.6 & 30.0 & 1.6 & 68.7 & 27.9 & 3.2 \\
LV407 & 39.0 & 60.7 & 0.1 & 22.5 & 76.5 & 0.9 \\
LV408p & 50.6 & 44.9 & 4.1 & 53.2 & 34.7 & 11.4 \\
LV409p & 55.7 & 39.5 & 4.2 & 46.9 & 43.5 & 9.3 \\
LV410p & 78.9 & 18.5 & 2.2 & 71.5 & 21.5 & 6.6 \\
LV411p & 68.0 & 27.0 & 4.6 & 62.2 & 26.2 & 10.9 \\
LV412p & 67.5 & 28.6 & 3.3 & 59.1 & 29.6 & 10.8 \\
LV413p & 69.1 & 26.7 & 3.3 & 70.2 & 19.5 & 9.9 \\
LV415p & 70.5 & 21.7 & 6.6 & 62.3 & 20.0 & 17.3 \\
LV416p & 46.5 & 38.5 & 14.0 & 34.7 & 37.6 & 27.1 \\
LV417p & 65.9 & 26.0 & 6.9 & 56.9 & 27.7 & 14.8 \\
LV418p & 37.9 & 39.2 & 21.6 & 40.6 & 24.6 & 34.1 \\
LV419p & 55.9 & 30.4 & 12.5 & 45.5 & 27.9 & 25.8 \\
LV420p & 57.3 & 34.6 & 6.9 & 55.4 & 29.3 & 14.7 \\
LV421p & 77.9 & 19.0 & 2.1 & 73.4 & 18.9 & 6.7 \\
LV422p & 59.8 & 36.1 & 3.2 & 57.1 & 36.6 & 5.6 \\
LV423p & 69.8 & 19.8 & 8.9 & 54.6 & 22.1 & 21.7 \\
LV424p & 59.3 & 32.3 & 6.6 & 56.8 & 25.8 & 16.5 \\
\hline
\end{tabular}

T-tests for Differences in Means between Males and Females (p-value)

\begin{tabular}{|c|c|c|c|}
\hline & Soph & Unsph & DK \\
\hline LV406 & 0.203 & 0.029 & 0.004 \\
\hline LV407 & 0.000 & 0.000 & 0.018 \\
\hline LV408p & 0.459 & 0.000 & 0.000 \\
\hline LV409p & 0.002 & 0.266 & 0.000 \\
\hline LV410p & 0.010 & 0.525 & 0.000 \\
\hline LV411p & 0.016 & 0.325 & 0.000 \\
\hline LV412p & 0.003 & 0.944 & 0.000 \\
\hline LV413p & 0.865 & 0.008 & 0.000 \\
\hline LV415p & 0.015 & 0.194 & 0.000 \\
\hline LV416p & 0.001 & 0.124 & 0.000 \\
\hline LV417p & 0.000 & 0.523 & 0.000 \\
\hline LV418p & 0.376 & 0.000 & 0.000 \\
\hline LV419p & 0.000 & 0.523 & 0.000 \\
\hline LV420p & 0.140 & 0.098 & 0.000 \\
\hline LV421p & 0.037 & 0.892 & 0.000 \\
\hline LV422p & 0.089 & 0.855 & 0.001 \\
\hline LV423p & 0.000 & 0.967 & 0.000 \\
\hline LV424p & 0.021 & 0.194 & 0.000 \\
\hline
\end{tabular}

Note: See Table 1. 
Table 7: Financial Sophistication by Education

\begin{tabular}{|c|c|c|c|c|c|c|c|c|c|c|c|c|c|}
\hline & \multicolumn{3}{|c|}{$\begin{array}{l}\text { Less Than High } \\
\text { School }(\mathrm{N}=273)\end{array}$} & \multicolumn{3}{|c|}{$\begin{array}{c}\text { High School } \\
\text { Graduate }(\mathrm{N}=455)\end{array}$} & \multicolumn{3}{|c|}{$\begin{array}{l}\text { Some College } \\
(\mathrm{N}=292)\end{array}$} & \multicolumn{4}{|c|}{$\begin{array}{l}\text { College Graduate } \\
\text { Plus (N=312) }\end{array}$} \\
\hline & Soph & Unsph & DK & Soph & Unsph & DK & Soph & Unsph & DK & ph & Unsph & DK & \\
\hline LV406 & 56.1 & 35.7 & 5.6 & 63.5 & 34.3 & 2.2 & 68.9 & 29.4 & 1.5 & 79.8 & & 18.2 & 1.9 \\
\hline LV407 & 4.0 & .9 & & 7.8 & & 0.5 & 34.0 & 65.8 & 0.0 & 49.3 & & 50.1 & 0.7 \\
\hline LV408p & 45.3 & 37.8 & 15.6 & 53.6 & & 7.9 & 50.2 & 41.9 & 7.6 & 55.4 & & 39.1 & 4.7 \\
\hline & 31.4 & 5 & 14.1 & 43.0 & & 7.8 & 56.2 & 39.5 & 3.9 & 66.2 & & 28.7 & 4.8 \\
\hline & 59.4 & 30.6 & 9.4 & 71.7 & & 5.8 & 77.7 & 20.2 & 1.5 & 84.5 & & & 3.2 \\
\hline & 42.4 & & 14.7 & 61.3 & & 10.4 & 69.5 & 25.1 & 5.1 & 77.4 & & 18 & 4.2 \\
\hline & .2 & & 1 & 56.8 & & 9.2 & 67.9 & & 6.3 & 76.9 & & 20.4 & 2.3 \\
\hline & 61.4 & 6 & 12.2 & 70.2 & 9 & 7.5 & 71.9 & 23.3 & 4.6 & 72.0 & & 22.3 & 5.4 \\
\hline & 57.5 & 6 & 22.6 & 64.4 & & 12.6 & 67.7 & 20.8 & 10.8 & 71.0 & & 19.8 & 8.2 \\
\hline & 23.5 & 50.8 & 24.5 & 39.6 & & 22.4 & 39.2 & 41.1 & 18.9 & 50.2 & & 29.4 & 20.0 \\
\hline & 36.4 & & & 56.7 & & 12.5 & 62.2 & 8 & 10.3 & 78.5 & & & 5.9 \\
\hline & 41.7 & & & 39.6 & & 30.1 & 39.6 & & 27.9 & 37.6 & & & 27.0 \\
\hline & 38.7 & & 25.6 & 46.3 & 28.9 & 23.8 & 50.4 & 32.2 & 16.4 & 60.9 & & 23.5 & 14.9 \\
\hline & 43.4 & 35.8 & 19.5 & 52.2 & 34.6 & 12.3 & 57.2 & 33.5 & 8.4 & 67.2 & & 24.5 & 7.7 \\
\hline 121p & 55.0 & 31.1 & 11.2 & 70.8 & 23.3 & 5.0 & 82.2 & 13.9 & 3.4 & 86.4 & & 11.6 & 1.7 \\
\hline & 41.7 & 46.8 & 10.1 & 56.7 & 37.0 & 5.6 & 59.3 & 37.2 & 2.9 & 68.5 & & 29.3 & 1.4 \\
\hline & 43.2 & 28 & 2 & 56.5 & & 18.6 & 65.3 & & 12.8 & 73.9 & & 13.7 & 10.3 \\
\hline LV424p & 46.8 & 35.0 & 16.7 & 53.5 & 31.2 & 13.6 & 62.4 & 25.7 & 11.2 & 65.3 & & 24.9 & 8.5 \\
\hline
\end{tabular}

T-tests for Differences in Means between T-tests for Differences in Means between Some LTHS and High School Grad (p-value) College and College Graduate Plus (p-value)

\begin{tabular}{|c|c|c|c|c|c|c|}
\hline & Soph & Unsph & DK & Soph & Unsph & DK \\
\hline LV406 & 0.031 & 0.685 & 0.002 & 0.002 & 0.002 & 0.939 \\
\hline LV407 & 0.081 & 0.445 & 0.013 & 0.000 & 0.000 & 0.088 \\
\hline LV408p & 0.011 & 0.715 & 0.002 & 0.095 & 0.654 & 0.016 \\
\hline LV409p & 0.015 & 0.665 & 0.012 & 0.000 & 0.000 & 0.781 \\
\hline LV410p & 0.000 & 0.005 & 0.020 & 0.006 & 0.009 & 0.756 \\
\hline LV411p & 0.000 & 0.001 & 0.010 & 0.002 & 0.012 & 0.237 \\
\hline LV412p & 0.000 & 0.123 & 0.004 & 0.010 & 0.285 & 0.004 \\
\hline LV413p & 0.001 & 0.090 & 0.006 & 0.527 & 0.665 & 0.780 \\
\hline LV415p & 0.005 & 0.864 & 0.000 & 0.632 & 0.226 & 0.031 \\
\hline LV416p & 0.002 & 0.066 & 0.169 & 0.001 & 0.008 & 0.672 \\
\hline LV417p & 0.000 & 0.003 & 0.016 & 0.000 & 0.006 & 0.027 \\
\hline LV418p & 0.453 & 0.464 & 0.957 & 0.712 & 0.243 & 0.587 \\
\hline LV419p & 0.005 & 0.059 & 0.219 & 0.012 & 0.097 & 0.358 \\
\hline LV420p & 0.006 & 0.547 & 0.002 & 0.043 & 0.140 & 0.490 \\
\hline LV421p & 0.000 & 0.021 & 0.000 & 0.001 & 0.022 & 0.014 \\
\hline LV422p & 0.000 & 0.006 & 0.017 & 0.043 & 0.142 & 0.102 \\
\hline LV423p & 0.001 & 0.066 & 0.053 & 0.004 & 0.039 & 0.078 \\
\hline LV424p & 0.053 & 0.371 & 0.088 & 0.035 & 0.160 & 0.152 \\
\hline
\end{tabular}

Note: See Table 1. 
Table 8: Financial Sophistication by Age

\begin{tabular}{|c|c|c|c|c|c|c|c|c|c|}
\hline & \multicolumn{3}{|c|}{ Ages 50-64 (N=430) } & \multicolumn{3}{|c|}{ Ages $65-75(\mathrm{~N}=518)$} & \multicolumn{3}{|c|}{ Ages $75+(N=384)$} \\
\hline & Soph & Unsph & DK & Soph & Unsph & DK & Soph & Unsph & DK \\
\hline LV406 & 75.0 & 23.2 & 1.8 & 67.6 & 29.2 & 2.4 & 54.3 & 40.4 & 4.3 \\
\hline LV407 & 32.7 & 66.8 & 0.5 & 31.8 & 67.5 & 0.6 & 21.5 & 77.3 & 0.6 \\
\hline LV408p & 51.9 & 41.6 & 6.2 & 54.1 & 37.1 & 8.7 & 49.7 & 37.0 & 11.8 \\
\hline LV409p & 55.7 & 38.0 & 6.2 & 50.0 & 42.5 & 7.1 & 41.5 & 48.8 & 8.6 \\
\hline LV410p & 77.7 & 18.5 & 3.7 & 75.8 & 19.3 & 4.9 & 67.5 & 24.9 & 6.2 \\
\hline LV411p & 69.9 & 23.4 & 6.5 & 63.6 & 27.1 & 8.7 & 55.3 & 32.7 & 10.7 \\
\hline LV412p & 63.9 & 29.7 & 6.3 & 64.9 & 26.0 & 8.6 & 57.9 & 31.9 & 8.4 \\
\hline LV413p & 72.1 & 21.4 & 6.5 & 69.7 & 23.8 & 5.9 & 64.6 & 24.3 & 9.3 \\
\hline LV415p & 66.5 & 23.2 & 10.2 & 67.4 & 19.5 & 12.2 & 63.2 & 16.8 & 17.7 \\
\hline LV416p & 39.9 & 38.3 & 21.7 & 41.5 & 37.8 & 20.3 & 38.4 & 37.7 & 21.5 \\
\hline LV417p & 66.1 & 23.9 & 9.9 & 63.4 & 25.3 & 10.4 & 46.8 & 35.7 & 15.0 \\
\hline LV418p & 39.4 & 32.9 & 27.6 & 43.0 & 28.9 & 27.0 & 34.7 & 30.4 & 32.2 \\
\hline LV419p & 55.2 & 29.3 & 15.3 & 48.8 & 27.8 & 22.2 & 40.9 & 29.8 & 26.5 \\
\hline LV420p & 56.8 & 32.8 & 10.3 & 55.8 & 31.9 & 11.5 & 55.4 & 29.0 & 12.7 \\
\hline LV421p & 77.4 & 18.5 & 3.7 & 75.4 & 18.1 & 6.1 & 71.2 & 21.2 & 4.9 \\
\hline LV422p & 62.7 & 34.1 & 3.2 & 54.9 & 39.1 & 5.5 & 53.0 & 38.0 & 6.1 \\
\hline LV423p & 64.3 & 22.4 & 12.1 & 61.5 & 19.5 & 18.3 & 55.0 & 20.2 & 21.2 \\
\hline LV424p & 62.3 & 28.2 & 9.1 & 58.0 & 27.8 & 12.8 & 48.2 & 30.9 & 17.6 \\
\hline
\end{tabular}

T-tests for Differences in Means between Ages 50-64 and Ages 65-74
T-tests for Differences in Means between Ages 65-75 and Ages 75+ (pvalue)

\begin{tabular}{|c|c|c|c|c|c|c|}
\hline & Soph & Unsph & DK & Soph & Unsph & DK \\
\hline LV406 & 0.004 & 0.005 & 0.965 & 0.000 & 0.001 & 0.204 \\
\hline LV407 & 0.433 & 0.365 & 0.755 & 0.003 & 0.004 & 0.774 \\
\hline LV408p & 0.547 & 0.187 & 0.187 & 0.256 & 0.898 & 0.224 \\
\hline LV409p & 0.102 & 0.374 & 0.258 & 0.351 & 0.538 & 0.769 \\
\hline LV410p & 0.161 & 0.341 & 0.307 & 0.264 & 0.339 & 0.823 \\
\hline LV411p & 0.015 & 0.095 & 0.261 & 0.425 & 0.488 & 0.990 \\
\hline LV412p & 0.942 & 0.220 & 0.140 & 0.364 & 0.175 & 0.338 \\
\hline LV413p & 0.480 & 0.653 & 0.956 & 0.135 & 0.667 & 0.137 \\
\hline LV415p & 0.559 & 0.243 & 0.061 & 0.477 & 0.575 & 0.278 \\
\hline LV416p & 0.318 & 0.794 & 0.273 & 0.193 & 0.952 & 0.357 \\
\hline LV417p & 0.430 & 0.699 & 0.774 & 0.006 & 0.073 & 0.303 \\
\hline LV418p & 0.508 & 0.173 & 0.751 & 0.012 & 0.187 & 0.413 \\
\hline LV419p & 0.059 & 0.448 & 0.004 & 0.066 & 0.499 & 0.374 \\
\hline LV420p & 0.213 & 0.460 & 0.578 & 0.662 & 0.406 & 0.754 \\
\hline LV421p & 0.099 & 0.429 & 0.131 & 0.841 & 0.732 & 0.181 \\
\hline LV422p & 0.010 & 0.126 & 0.040 & 0.698 & 0.828 & 0.983 \\
\hline LV423p & 0.508 & 0.156 & 0.015 & 0.557 & 0.333 & 0.444 \\
\hline LV424p & 0.145 & 0.623 & 0.016 & 0.062 & 0.729 & 0.132 \\
\hline
\end{tabular}

Note: See Table 1. 
Table 9: Financial Sophistication by Race/Ethnicity

\begin{tabular}{|c|c|c|c|c|c|c|c|c|c|}
\hline & \multicolumn{2}{|c|}{$\begin{array}{c}\text { White } \\
(\mathrm{N}=980)\end{array}$} & \multicolumn{3}{|c|}{$\begin{array}{c}\text { African-American } \\
(\mathrm{N}=189)\end{array}$} & \multicolumn{3}{|c|}{$\begin{array}{l}\text { Hispanic } \\
(\mathrm{N}=135)\end{array}$} & \multirow[b]{2}{*}{ DK } \\
\hline & Soph & Unsph & DK & Soph & Unsph & DK & Soph & Unsph & \\
\hline LV406 & 69.8 & 28.0 & 1.9 & 70.8 & 25.4 & 2.3 & 47.2 & 43.4 & 8.2 \\
\hline LV407 & 33.0 & 66.6 & 0.4 & 20.8 & 78.6 & 0.6 & 14.6 & 81.8 & 2.4 \\
\hline LV408p & 53.9 & 39.2 & 6.4 & 43.9 & 40.6 & 14.8 & 38.3 & 42.1 & 18.3 \\
\hline LV409p & 53.1 & 40.9 & 5.6 & 47.4 & 42.4 & 9.3 & 35.0 & 45.2 & 18.5 \\
\hline LV410p & 75.7 & 20.0 & 4.0 & 71.1 & 23.6 & 4.3 & 72.2 & 15.0 & 11.6 \\
\hline LV411p & 68.9 & 24.4 & 6.3 & 47.5 & 36.9 & 14.6 & 46.1 & 31.9 & 20.8 \\
\hline LV412p & 68.2 & 25.8 & 5.5 & 46.7 & 38.4 & 14.0 & 35.7 & 42.0 & 21.1 \\
\hline LV413p & 72.2 & 21.5 & 5.7 & 66.0 & 24.4 & 9.5 & 51.3 & 31.6 & 16.1 \\
\hline LV415p & 66.4 & 21.7 & 11.1 & 67.7 & 15.4 & 16.0 & 53.9 & 19.2 & 25.9 \\
\hline LV416p & 42.3 & 36.1 & 20.9 & 31.0 & 45.6 & 22.5 & 27.4 & 43.7 & 27.5 \\
\hline LV417p & 66.8 & 23.0 & 9.3 & 34.1 & 48.4 & 16.6 & 30.6 & 41.5 & 26.5 \\
\hline LV418p & 39.3 & 31.8 & 28.0 & 43.0 & 28.1 & 27.4 & 35.1 & 25.2 & 38.2 \\
\hline LV419p & 53.1 & 27.9 & 18.1 & 34.7 & 36.6 & 27.2 & 38.9 & 25.7 & 34.0 \\
\hline LV420p & 60.0 & 30.0 & 9.2 & 43.6 & 37.3 & 18.0 & 37.3 & 34.5 & 26.8 \\
\hline LV421p & 77.8 & 17.7 & 3.5 & 70.5 & 23.6 & 5.6 & 59.0 & 24.8 & 15.3 \\
\hline LV422p & 61.1 & 34.3 & 3.7 & 48.9 & 47.4 & 3.3 & 39.6 & 45.1 & 14.4 \\
\hline LV423p & 65.4 & 18.1 & 14.8 & 46.6 & 36.7 & 16.4 & 36.6 & 33.2 & 27.5 \\
\hline LV424p & 58.9 & 28.7 & 11.1 & 56.2 & 28.8 & 13.9 & 47.0 & 29.4 & 20.6 \\
\hline
\end{tabular}

T-tests for Differences in Means between White

T-tests for Differences in Means between and African-American Respondents (p-value)

\begin{tabular}{ccccccc}
\hline & Soph & Unsph & DK & Soph & Unsph & DK \\
\hline LV406 & 0.327 & 0.571 & 0.262 & 0.000 & 0.019 & 0.000 \\
LV407 & 0.030 & 0.029 & 0.982 & 0.000 & 0.003 & 0.000 \\
LV408p & 0.029 & 0.480 & 0.009 & 0.004 & 0.948 & 0.000 \\
LV409p & 0.011 & 0.512 & 0.001 & 0.000 & 0.294 & 0.000 \\
LV410p & 0.640 & 0.752 & 0.233 & 0.001 & 0.748 & 0.000 \\
LV411p & 0.000 & 0.001 & 0.002 & 0.000 & 0.206 & 0.000 \\
LV412p & 0.000 & 0.007 & 0.000 & 0.000 & 0.000 & 0.000 \\
LV413p & 0.117 & 0.238 & 0.290 & 0.000 & 0.000 & 0.000 \\
LV415p & 0.279 & 0.457 & 0.015 & 0.003 & 0.874 & 0.000 \\
LV416p & 0.033 & 0.036 & 0.962 & 0.002 & 0.206 & 0.038 \\
LV417p & 0.000 & 0.000 & 0.115 & 0.000 & 0.004 & 0.000 \\
LV418p & 0.519 & 0.406 & 0.945 & 0.148 & 0.733 & 0.250 \\
LV419p & 0.002 & 0.182 & 0.028 & 0.022 & 0.894 & 0.003 \\
LV420p & 0.000 & 0.096 & 0.003 & 0.000 & 0.716 & 0.000 \\
LV421p & 0.000 & 0.001 & 0.001 & 0.000 & 0.123 & 0.000 \\
LV422p & 0.010 & 0.024 & 0.262 & 0.000 & 0.020 & 0.000 \\
LV423p & 0.001 & 0.000 & 0.472 & 0.000 & 0.000 & 0.001 \\
LV424p & 0.024 & 0.093 & 0.253 & 0.003 & 0.749 & 0.000 \\
\hline Note: See & 1. & & & & &
\end{tabular}

Note: See Table 1. 